\title{
CIVIL ACTIVISM AND DEVELOPMENT OF DEMOCRACY IN NIGERIA (2011-2019).
}

\author{
Onwuama, Emeka Micheal Ph.D. \\ Humanities Unit, School of General Studies \\ University of Nigeria, Nsukka \\ emeka.onwuama@unn.edu.ng \\ Ibutot, Emmanuel J. \\ Humanities Unit, School of General Studies \\ University of Nigeria, Nsukka \\ Email: emmanuel.ibuot@unn.edu.ng
}

\begin{abstract}
The study focused on civil activism and development of democracy in Nigeria 2011-2019. Civil activism played immense role in agitation for military exit in Nigerian politics, they have not done enough to nurture the democracy. The specific objectives are to: examine the effect of individual effort to promote effective participation and rights to run for office in Nigeria from 2011-2019 and evaluate the effect of civil rights on freedom of expression and associations in Nigeria from 2011-2019.The quantitative and qualitative were used in collection data. The quantitative data provides a general picture of the research problem and qualitative was to refine, extend or explain the picture. In gathering quantitative data, which is the first approach in explanatory mixed method, the opinion of the populace or residents, through survey method (questionnaire), was analysed. The target population 952,410 (Nine hundred and fifty two thousand, four hundred and ten) made up of the residence of Enugu metropolis that comprised three local governments namely Enugu North, Enugu East and Enugu south Local governments. The sample size of 384 was determined by the use Freund and Williams's formula. 322 staff returned the questionnaire and accurately filled. That gave 84 percent response rate. Data was presented and analyzed by mean score (3.0 and above agreed while below 3.0 disagreed) and standard deviation using Sprint Likert Scale. The hypotheses were analyzed using F-statistics (ANOVA) tool. The findings of the study showed that individual effort has positive significant effect to promote effective participation and rights to run for office in Nigeria $\mathrm{F}\{95, \mathrm{n}=384\}=60.941, \mathrm{p} .<0.5$; civil rights have positive significant effect on freedom of expression and associations in Nigeria, $F\{95, n=$ $384\}=175.861$, p. $<0.5$. The study concluded that Nigeria remains at a crisis, due to deepseated ethnic animosity as well as the failure of contemporary activism and civil society to redeem the nation from schismatic ills rooted in its colonial foundations. The study recommended that government should collaborate and render free legal services to transparency, equity, accountability, freedom of speech, thought, association, advocacy, civic education, judicial freedom and accessibility, economic and social empowerment in the democratic process.
\end{abstract}

Keywords: Civil activism, development, democracy, Freedom of expression. 


\subsection{Introduction}

Activism is all around us, but its mechanics are little understood and explanations are often distinctive, focusing on particular activism efforts rather than practical exploring broad patterns (Mary, 2014). It has often been maintained that political democracy has a negative impact on economic growth, particularly in less developed countries. Development is basically an economic concept that has positive connotations; it involves the application of certain economic and technical measures to utilize available resources to prompt economic growth and improve people's quality of life.In the last half a century, many countries have transited to democracy (EIU,2010). Democracy and development are global phenomena;every country in the world aspires and claims to be democratic. This is because of the role of the latter in developmental process. The growth and development of democracy depends largely on the practice of its ethics, ideals and norms as they serve as bedrock for democratic consolidation and sustainability. By and large, democracy has principles, which can also be described as rules guiding its practice, these rules or principles are otherwise regarded as democratic ethics or norms (Tolu andOgunro, 2012).

Civil activism appears to play important role in social, political and economic development activities. The transformation of any society or system, particularly the developing societies like Nigeria depend on the effectiveness and efficiency of its civil societies (OmedeandBakare, 2014).Democracy is a system of processing clashin which outcomes depend on what participants do, but no single force controls what occurs and its outcomes andthe uncertainty of outcomes is inherent in democracy(Ake, 1996). Democracy is about effective and efficient representation and delivery of the dividends of good governance to the masses (Diamond 1992, Aiyede 2003). Based on the background of the study,it attempts to examinethe civil activism and development of democracy in Nigeria.

\subsection{Statement of the Problem}

Democracy is the government of the people by the people and for the people has not been sufficiently rooted and realized. Democracy connotes the practice whereby citizens of a state take part in the making and implementation of the decision and policies that affect their welfare and general standard living. Democracy offers a level playing ground for competition into political offices. But this makes sense only when competition is diluted by the spirit of tolerance and compromise. However, the Nigerian political elites have neglected this aspect that gives meaning to the democratic project thereby plunging it into crisis.

Developmental programmes enlighten the minds of the people to know the importance of democracy. Based on this democracy has not achieved much success in bequeathing to the people their basic needs or even the requirement in decision-making. The basic problem of development and democracy in Nigeria ispoor individual effort to promote effective participation and rights to run for office and poor civil rights on freedom of expression and associations in Nigeria government.

Civil activism providesthe necessary social lubricants that interface between the government and the citizens especially inthe promotion of good democratic governance.Civil society provides the necessary social lubricants that interface between the government and the citizens especially in the promotion of good democratic governance. Despite the highlighted efforts, certain challenges limit effectiveness a disconnection from rural organizations, lack of unity, inadequate funding, government patronage, lack of internal democracy, amongst others.

\subsection{Objectives of the Study}

The broad objective of the study was to examine the civil activism and development of democracy in Nigeria (2011-2019). The specific objectives are to: 
i. Examine the effect of individual effort to promote effective participation and rights to run for office in Nigeria from 2011-2019.

ii. Evaluate the effect of civil rights on freedom of expression and associations in Nigeria from 2011-2019.

\subsection{Research Questions}

i. What is the effect of individual effort to promote effective participation and rights to run for office in Nigeria from 2011-2019?

ii. What is the effect of civil rights on freedom of expression and associations in Nigeria from 2011-2019?

\subsection{Statement of the Hypotheses}

The following alternate hypotheses guided the study.

i. Individual efforthas positive significant effect to promote effective participation and rights to run for office in Nigeria from 2011-2019

ii. Civil rights has positive significant effect on freedom of expression and associations in Nigeria from 2011-2019.

\subsection{Significance of the Study}

The study is significance because; democracy and development are global phenomena. Every country in the world aspires and claims to be democratic. This is because of the role of the latter in developmental process. The study examined the linkage between democracy and development in Nigeria, using ethics as the yardstick for democratic adherence. One of the contributions of democratic practices has been the development of a system of checks and balances to ensure that political power is dispersed and decentralized. It is a system founded on the deeply held belief that government is best when its potentials for abuse are curbed and when it is held as close to the people as possible. That is the reason why democracy as a system of government is now the most central and ascendant idea in world politics.

\section{Review of Related Literature}

\subsection{Conceptual Framework}

\subsubsection{Development}

Development is often regarded as something that is done by one group to another. Again, this demonstrates that development is a political process, because it raises questions about who has the power to do what to whom. The idea of development articulated by the World Bank, for instance, is very different from that promoted by Greenpeace activists. This point has important implications for the task of understanding sustainable development, because much of the confusion about the meaning of the term 'sustainable development' arises because people hold very different ideas about the meaning of 'development' (Adams, 2009). In economic growth, development means an increase in the size or pace of the economy such that more products and services are produced. Conventionally, a common assumption has been that, if an economy generates more products and services, then humans will enjoy a higher standard of living. The aim of many conventional approaches to development has been to increase the size of the economy (economic growth) in order to increase the output of products and services (Owen, 2012).

\subsubsection{Democracy}

Democracy is a vital instrument that propels political proficiency, economic development and social stability of any nation state. Democracy in Nigeria has been a mere political 
desideratum hanging on a limping utopia. A true democracy is a sine qua non for the development of all sectors of any country's economy. As observed by Nwanolue and Ojukwu (2012), the general success of any practicing democracy is deeply incumbent upon three major challenges. The principle of democracy which includes popular participation of citizens in the policy process, guaranteeing of fundamental human rights and press freedom is known as the precursor of development in every society (Adejumobi, 2004). Democracy is about equality and elimination of discriminations irrespective of race, class or ethno-religious or cultural affiliations. In this perspective, Ikelegbe (2017) asserts that civil society organizations ensure that there is adequate constitutional provisions that promote equity and to also monitor and advocate for its implementation and practice in a democratic nation. It is expected that civil society stimulate good democratic governance by promoting equity in all ramifications especially by reporting cases of discriminations to the public. Furthermore, they help to reform victims of racial, ethnic or cultural discriminations by rendering instant psychological and socio-economic stop-gap measures.

\subsubsection{Freedom of Expression and Association in Nigeria}

Everyone has the right to freedom of opinion and expression; this right includes freedom to hold opinions without interference and to seek, receive and impart information and ideas through any media and regardless of frontiers. This right is also one of the basic tenets of the rule of law in Nigeria. Freedom of expression is the right to express one's ideas and opinions freely through speech, writing, and other forms of communication but without deliberately causing harm to others' character and/or reputation by false or misleading statements (Business Dictionary, 2019). Freedom of expression is essential in informing and facilitating the realisation of other fundamental human rights. It is particularly important in situations where human rights abuses are occurring. The rights to freedom of opinion and expression grant all people the right to express themselves and to seek, receive and impact information through any medium. Freedom of expression is the right to communicate one's opinions and ideas without fear of government retaliation or censorship. Freedom of expression consists of two elements: the first is the freedom to seek, receive and impart information and ideas of all kinds, regardless of frontiers and the second is the right to choose the means to do so (Ofoegbu, 2013).

Freedom of expression serves as a viable tool in advancing the cause of liberty in Nigeria because it underpins most other rights and allows them to flourish. The rights of individuals to have access to information, speak their minds freely on important issues in society, and hold the powerful and influential people to account where necessary plays a vital role in the healthy development process of such society.The lack of freedom of expression is a problem that most particularly affects the already marginalized individuals and groups in the society such as ethnic and religious minorities(Ojekunle, 2017).Freedom of speech and adequate access to information is pillars of a healthy democratic society and means to advance liberty for social and economic growth, allowing for the free flow of ideas necessary for innovation and bolstering accountability and transparency (Ojekunle, 2017).

\subsubsection{Individual Promotion and Participant in Democratic Society}

Individual effort is nothing more than the best at every one of those starts. Not the starts put together in one match, but individually.Participation is not a fixed notion, but is deeply embedded within our political realities and thus is the object of long-lasting and intense ideological struggles (Carpentier, 2012). Meaningful and effective participation of rights holders must be a key component of any social protection system. This is what builds trust and public support behind schemes and ensures that there is a sense of ownership. The participation of right holders is important during the social protection policy making 
processes but also as regards the involvement of relevant stakeholders in the governance of social protection schemes. As well as being an inherent right, participation has the additional advantage of allowing authorities to improve the design and delivery of services. In order to ensure meaningful and effective participation, participatory channels should take into account existing asymmetries of power, patterns of marginalization and gender inequalities that exist within the household and the community. The adoption of specific measures to encourage the inclusion and participation of women, persons with disabilities, indigenous peoples, ethnic minorities, older persons and other groups that experience structural discrimination is often necessary to ensure that stakeholders are able to exercise their rights (Social Protection and Human Rights (2019).

\subsubsection{Civil Right in Nigeria}

Civil and political rights are a class of rights that protect individuals' freedom from infringement by governments, social organizations, and private individuals (The Civil Rights act of 1964). They ensure one's entitlement to participate in the civil and political life of the society and state without discrimination or repression (Abbott, 2019).Civil right is an enforceable right or privilege, which if interfered with by another gives rise to an action for injury. Discrimination occurs when the civil rights of an individual are denied or interfered with because of the individual's membership in a particular group or class.Civil rights include the ensuring of peoples' physical and mental integrity, life, and safety; protection from discrimination on grounds such as race, gender, sexual orientation, national origin, color, age, political affiliation, ethnicity, religion, and disability; and individual rights such as privacy and the freedom of thought, speech, religion, press, assembly, and movement (Regilme, 2014).

\subsection{Theoretical Framework}

\subsubsection{Liberal theory}

Liberal theory of civil society holds that the existence of civil society is highly imperative in a democratic society because it promotes freedom, equality, tolerance, accountability and progress. Liberalism is a negation to autocratic ideology and is sine qua non to democracy. As a political ideology, liberalism espouses citizen's freedom of association, expression, thought among others (Fadakinte 2013). To the liberals, civil society is crucial in any democratic nation, especially in a multi-ethnic society because it promotes unrestricted freedom, tolerance, and equity, freedom of expression and association which is germane for building a violent free democratic society. By providing guidelines and legal provisions for openness and freedom, citizens are better informed and empowered to participate in governance. The survival of these liberal tenets inhibits the emergence of dictators and attenuates democratic culture.

\subsubsection{Democratic Theory}

Democratic theory is an established subfield of political theory that is primarily concerned with examining the definition and meaning of the concept of democracy, as well as the moral foundations, obligations, challenges, and overall desirability of democratic governance. The theory was developed by Balot in the year 2009. Generally speaking, a commitment to democracy as an object of study and deliberation is what unites democratic theorists across a variety of academic disciplines and methodological orientations. When theorists concern themselves with the ways in which actual democracies function, their theories are empirical,democratic balance the notion of participation which refers to the involvement of the citizenry with politics, although the field of democratic theory is extensive and characterized by an almost unsettling degree of diversity. Finally, when democratic theorists 
interrogate or formulate the meaning of the concept of democracy, their work is conceptual or semantic in orientation (Michael, 2017).

\subsection{Empirical Framework}

In view of the study of Chukwudi (2017) examined the political culture, democracy and development in Nigeria. Democracy and development have continued to attract some mainstream social science attention. The objective of the study was to examine the relationship among political culture, democracy and development in Nigeria. The study adopted logical argumentation method. The study showed that development paradigms Nigeria's political culture is indeed leading the country to some undesirable destination. The study recommended that the call for the convocation of a national conference which would create a road-map for coexistence among the people of Nigeria in order to democratize development in the country.

Osondu (2014) conducted a study on democracy and political participation in Nigeria: The case of Imo State in the 2007 general elections. The study evaluated Nigerian democracy in the context of political participation, to find out the position of the Nigerian citizen in the operation of the democracy. The study also revealed the negative attitude of Nigerians especially in the 2007 general elections in Imo State, towards political activities that gave meaning to democracy. The study made use of survey technique. The study showed that The findings show that the Nigerian type of democracy is conditioned by certain environmental factors that tend to water down the democratic principles. The study concludes that an effective democracy requires more than free and fair elections and majority rule. The study recommended that establishment of a mobilization commission as may be provided by the constitution that will train, retain and mobilize the people right from the grass root level.

Majekodunmi (2012) conducted a study on the democratization and development in Nigeria: The Fourth Republic in Perspective. The study examined the nexus among the 'embattled duo,' using a contextual analysis of the Nigerian experience under the fourth republic. The study found that the present state of democratization in Nigeria gives cause for concern, as it tends towards the direction of disempowerment. The study concludes democratization, defined the process of transition to a stable/consolidated democracy, could be a harbinger of development. The study recommended that addressing the problem of democratization and development must involve all the stakeholders.

Akeem, (2010) conducted a study on repression of press freedom in Nigerian democratic dispensations. The study was to examine the repression of press freedom in Nigerian democratic dispensations. The study adopted questionnaires and indepth interviews. Results showed that although the press facilitated the development of democracy, challenges to press freedom were frequent. The study concludes that that the proposed Freedom of Information Bill (FIB) would empower the press and promote democracy in Nigeria if passed into law and implemented. The study recommended that press organisations should pursue their professionalism and the ethics of journalism rather than succumb tosocio-political forces influencing the quantity and quality of informationmade available to the public.

Minn, Srisontisuk and Laohasiriwong (2010) conducted a study on promoting people's participation in solid waste management in Myanmar. The purpose of the study was to explore implementation strategies for fostering people's participation in solid waste management in Myanmar. The study employ mixed methods. The results of the study showed that the current participatory approach, which mainly focuses on raising awareness or imparting environmental education, is not adequate to maximize the people's participation in Myanmar due to the persistence of institutional and social constraints. The study recommended that motivation and interaction exist among all parties. 


\subsection{Methodology}

The quantitative and qualitative were used in collection data. The quantitative data provides a general picture of the research problem and qualitative was to refine, extend or explain the picture. In gathering quantitative data, which is the first approach in explanatory mixed method, the opinion of the populace or residents, through survey method(questionnaire), was analysed. The target population 952,410 (Nine hundred and fifty two thousand, four hundred and ten) made up of the residence of Enugu metropolis that comprised three local governments namely Enugu North, Enugu East and Enugu south Local governments. The sample size of 384 was determined by the use Freund and Williams formula. 322 staff returned the questionnaire and accurately filled. That gave 84 percent response rate. Data was presented and analyzed by mean score (3.0 and above agreed while below 3.0 disagreed) and standard deviation using Sprint Likert Scale. The hypotheses were analyzed using Fstatistics (ANOVA) tool.

\subsection{Data Presentation Analysis \\ 4.1 Likert Scale Analysis}

\section{Research question one.What is the effect of individual effort to promote effective participation and rights to run for office in Nigeria from 2011-2019?}

Table 4.1: Responses to research question one on the effect of individual effort to promote effective participation and rights to run for office in Nigeria from 2011-2019.

\begin{tabular}{|c|c|c|c|c|c|c|c|c|c|c|}
\hline & & $\begin{array}{c}5 \\
\text { SA }\end{array}$ & $\begin{array}{l}4 \\
\mathrm{~A}\end{array}$ & $\begin{array}{c}3 \\
\mathrm{~N}\end{array}$ & $\begin{array}{c}2 \\
\text { DA }\end{array}$ & $\begin{array}{c}1 \\
\text { SD }\end{array}$ & $\sum F X$ & $\begin{array}{l}- \\
X\end{array}$ & SD & Decision \\
\hline 1 & $\begin{array}{l}\text { There are personal rights } \\
\text { acquired by an individual by } \\
\text { being a citizen conferred by law } \\
\text { or customer. }\end{array}$ & $\begin{array}{c}100 \\
20\end{array}$ & $\begin{array}{l}736 \\
184\end{array}$ & $\begin{array}{c}117 \\
39\end{array}$ & $\begin{array}{c}104 \\
52\end{array}$ & $\begin{array}{l}27 \\
27\end{array}$ & $\begin{array}{c}1084 \\
322\end{array}$ & 3.4 & 1.089 & Agree \\
\hline 2 & $\begin{array}{l}\text { The right to equality enables any } \\
\text { one run a public office }\end{array}$ & $\begin{array}{l}700 \\
140\end{array}$ & $\begin{array}{l}327 \\
109\end{array}$ & $\begin{array}{l}72 \\
24\end{array}$ & $\begin{array}{l}60 \\
30\end{array}$ & $\begin{array}{l}19 \\
19\end{array}$ & $\begin{array}{c}1178 \\
322\end{array}$ & 3.7 & 1.191 & Agree \\
\hline 3 & $\begin{array}{l}\text { Individual physical and mental } \\
\text { integrity are maintained. }\end{array}$ & $\begin{array}{l}520 \\
104\end{array}$ & $\begin{array}{c}372 \\
93\end{array}$ & $\begin{array}{c}129 \\
43\end{array}$ & $\begin{array}{l}60 \\
30\end{array}$ & $\begin{array}{l}52 \\
52\end{array}$ & $\begin{array}{l}1133 \\
322\end{array}$ & 3.5 & 1.434 & Agree \\
\hline 4 & $\begin{array}{l}\text { Effort to maintain justice runs the } \\
\text { political life of the society }\end{array}$ & $\begin{array}{l}770 \\
154\end{array}$ & $\begin{array}{c}184 \\
46\end{array}$ & $\begin{array}{l}129 \\
43\end{array}$ & $\begin{array}{c}114 \\
57\end{array}$ & $\begin{array}{l}22 \\
22\end{array}$ & $\begin{array}{c}1219 \\
322\end{array}$ & 3.8 & 1.376 & Agree \\
\hline 5 & $\begin{array}{l}\text { Discrimination on the grounds } \\
\text { such race, gender, ethnicity etc. } \\
\text { are protected. }\end{array}$ & $\begin{array}{l}575 \\
115\end{array}$ & $\begin{array}{l}640 \\
160\end{array}$ & $\begin{array}{l}96 \\
32\end{array}$ & $\begin{array}{l}2 \\
1\end{array}$ & $\begin{array}{l}14 \\
14\end{array}$ & $\begin{array}{c}1327 \\
322\end{array}$ & 4.1 & .921 & Agree \\
\hline & $\begin{array}{l}\text { Total grand mean and } \\
\text { standard deviation }\end{array}$ & & & & & & & 3.7 & 1.202 & \\
\hline
\end{tabular}

\section{Source: Field Survey, 2019}

Table 4.1, agreed that there is personal rights acquired by an individual by being a citizen conferred by law or customer with mean score of 3.4 and standard deviation of 1.089, The right to equality enables any one run a public office with mean score of 3.7 and standard deviation of 1.191, individual physical and mental integrity are maintained with mean score of 3.5 and standard deviation of 1.434, it was agreed that effort to maintain justice runs the political life of the societywith mean score of 3.8 and 1.376, discrimination on the grounds such race, gender, ethnicity etc. are protected with a mean score of 4.1 and standard deviation of .921 . 
Research question Two: What is the effect of civil rights on freedom of expression and associations in Nigeria from 2011-2019?

Table 4.2: Responses to research question Two the effect of civil rights on freedom of expression and associations in Nigeria from 2011-2019.

\begin{tabular}{|c|c|c|c|c|c|c|c|c|c|c|}
\hline & & $\begin{array}{l}5 \\
\text { SA }\end{array}$ & $\begin{array}{l}4 \\
\mathrm{~A}\end{array}$ & $\begin{array}{l}3 \\
\mathrm{~N}\end{array}$ & $\begin{array}{l}2 \\
\text { DA }\end{array}$ & $\begin{array}{l}1 \\
\text { SD }\end{array}$ & $\sum \mathrm{FX}$ & $\bar{x}$ & SD & Decision \\
\hline 1. & $\begin{array}{l}\text { The diversion of school fees by } \\
\text { management has cursed poor } \\
\text { implementation of educational } \\
\text { policies }\end{array}$ & $\begin{array}{l}955 \\
191\end{array}$ & $\begin{array}{l}348 \\
87\end{array}$ & $\begin{array}{l}45 \\
15\end{array}$ & $\begin{array}{l}24 \\
12\end{array}$ & $\begin{array}{l}17 \\
17\end{array}$ & $\begin{array}{l}1389 \\
322\end{array}$ & 4.3 & 1.081 & Agree \\
\hline 2. & $\begin{array}{l}\text { The imposition of unauthorized } \\
\text { fees on the students has } \\
\text { undermined the national } \\
\text { educational development of } \\
\text { Nigeria }\end{array}$ & $\begin{array}{l}610 \\
122\end{array}$ & $\begin{array}{l}372 \\
93\end{array}$ & $\begin{array}{l}135 \\
45\end{array}$ & $\begin{array}{l}36 \\
18\end{array}$ & $\begin{array}{l}44 \\
44\end{array}$ & $\begin{array}{l}1197 \\
322\end{array}$ & 3.7 & 1.378 & Agree \\
\hline 3. & $\begin{array}{l}\text { Diversion of fund meant for } \\
\text { infrastructures and other } \\
\text { facilities have delayed the } \\
\text { progress implementation of } \\
\text { education policies }\end{array}$ & $\begin{array}{l}715 \\
143\end{array}$ & $\begin{array}{l}432 \\
108\end{array}$ & $\begin{array}{l}90 \\
30\end{array}$ & $\begin{array}{l}58 \\
29\end{array}$ & $\begin{array}{l}12 \\
12\end{array}$ & $\begin{array}{l}1307 \\
322\end{array}$ & 4.1 & 1.111 & Agree \\
\hline 4. & $\begin{array}{l}\text { The creation of unhealthy } \\
\text { environment by the government } \\
\text { has resulted in poor instructional } \\
\text { delivery. }\end{array}$ & $\begin{array}{l}755 \\
151\end{array}$ & $\begin{array}{l}428 \\
107\end{array}$ & $\begin{array}{l}93 \\
31\end{array}$ & $\begin{array}{l}34 \\
17\end{array}$ & $\begin{array}{l}16 \\
16\end{array}$ & $\begin{array}{l}1326 \\
322\end{array}$ & 4.1 & 1.102 & Agree \\
\hline 5 & $\begin{array}{l}\text { Scholarship diversion allocated } \\
\text { to the schools have made people } \\
\text { not to have access to education. }\end{array}$ & $\begin{array}{l}765 \\
153\end{array}$ & $\begin{array}{l}464 \\
116\end{array}$ & $\begin{array}{l}75 \\
25\end{array}$ & $\begin{array}{l}24 \\
12\end{array}$ & $\begin{array}{l}16 \\
16\end{array}$ & $\begin{array}{l}1344 \\
322\end{array}$ & 4.2 & 1.059 & Agree \\
\hline & $\begin{array}{l}\text { Total grand mean and } \\
\text { standard deviation }\end{array}$ & & & & & & & 4.1 & 1.146 & \\
\hline
\end{tabular}

The table 4.2, agreed that the diversion of school fees by management has cursed poor implementation of educational policies with mean score of 4.3 and standard deviation of 1.081, The imposition of unauthorized fees on the students has undermined the national educational development of Nigeria with mean score of 3.7 and standard deviation of 1.378, Diversion of fund meant for infrastructures and other facilities have delayed the progress implementation of education policies with mean score of 4.1 and standard deviation of 1.111, It was agreed that The creation of unhealthy environment by the government has resulted in poor instructional delivery with mean score of 4.1 and 1.102, Scholarship diversion allocated to the schools have made people not to have access to education with a mean score of 4.2 and standard deviation of 1.059 .

\subsection{Test of Hypotheses}

Hypothesis One: Individual effort has positive significant effect to promote effective participation and rights to run for office in Nigeria.

Model Summary

\begin{tabular}{|l|r|r|r|r|}
\hline Model & R & R Square & Adjusted R Square & Std. Error of the Estimate \\
\hline 1 & $.791^{\mathrm{a}}$ & .751 & .751 & .59707 \\
\hline
\end{tabular}

a. Predictors: (Constant), PER, EQU, PHY, MAI. DIS. 


\begin{tabular}{|c|c|c|c|c|c|c|}
\hline \multicolumn{7}{|c|}{ ANOVA $^{\mathrm{a}}$} \\
\hline & & Sum of Squares & Df & Mean Square & $\mathrm{F}$ & Sig. \\
\hline \multirow{3}{*}{1} & Regression & 108.627 & 5 & 21.725 & 60.941 & $.000^{\mathrm{b}}$ \\
\hline & Residual & 112.653 & 316 & .356 & & \\
\hline & Total & 221.281 & 321 & & & \\
\hline
\end{tabular}

a. Dependent Variable: INDI

b. Predictors: (Constant), PER, EQU, PHY, MAI. DIS.

Where

INDI = Individual effort has positive significant effect to promote effective participation and rights to run for office in Nigeria from 2011-2019

PER $=$ There is personal rights acquired by an individual by being a citizen conferred by law or customer

$\mathrm{EQU}=$ The right to equality enables any one run a public office

PHY = Individual physical and mental integrity are maintained.

MAI =Effort to maintain justice runs the political life of the society

DIS $=$ Discrimination on the grounds such race, gender, ethnicity etc. are protected.

The $\mathrm{R}^{2}\{\mathrm{R}$-Squared $\}$ which measures the overall goodness of fit of the entire regression, shows the value as .751 and adjusted to .751 . This means that $\mathrm{R}^{2}$ accounts for 75.1 percent approximately 75 percent. This indicates that the independent variables accounts for about 75 percent of the variation in the dependent variable. Which shows goodness of fit? From the result, F-calculated $\{60.941\}$ is greater than the F-tabulated $\{2.7858\}$, that is, F-cal $>$ F-tab. Hence, we reject the null hypothesis $\{\mathrm{H} 0\}$ and accept Alternative hypothesis which means that the overall estimate has a good fit which also implies that our independent variables are simultaneously insignificant. We now concluded from the analysis thatindividual effort has positive significant effect to promote effective participation and rights to run for office in Nigeria.

\section{Hypothesis Two: Civil rights has positive significant effect on freedom of expression and associations in Nigeria.}

Model Summary

\begin{tabular}{|c|c|c|c|c|}
\hline Model & $\mathrm{R}$ & R Square & Adjusted R Square & Std. Error of the Estimate \\
\hline 1 & $.774^{\mathrm{a}}$ & .739 & .738 & 18899 \\
\hline
\end{tabular}

a. Predictors: (Constant), THE,ONE,SEE, FRE,FLO

\begin{tabular}{|rl|r|r|r|r|r|}
\hline Model & & Sum of Squares & Df & Mean Square & \multicolumn{1}{c|}{ F } & Sig. \\
\hline \multirow{2}{*}{1} & Regression & 209.994 & 5 & 41.999 & 175.861 & $.000^{\mathrm{b}}$ \\
& Residual & 11.287 & 316 & .036 & & \\
& Total & 221.281 & 321 & & & \\
\hline
\end{tabular}

a. Dependent Variable: CIVI

b. Predictors: (Constant), THE,ONE,SEE, FRE,FLO

\section{Where}

CIVI = Civil rights has positive significant effect on freedom of expression and associations in Nigeria.

THE $=$ There is one's freedom in our country

ONE = One's idea and opinion are respected and upheld in the country.

SEE $=$ To seek, receive and impart information through any medium is allowed in the country. 
FRE $=$ Freedom of expression and access to a enough information has created a healthy democratic society

FLO $=$ The free flow of opinion and ideas has aided innovation and transparency in the society

The $\mathrm{R}^{2}$ \{R-Squared\} which measures the overall goodness of fit of the entire regression, shows the value as .739 and adjusted to .738 . This means that $\mathrm{R}^{2}$ accounts for 73.9 percent approximately 74 percent. This indicates that the independent variables accounts for about 74 percent of the variation in the dependent variable. Which shows goodness of fit? From the result, F-calculated $\{175.861\}$ is greater than the F-tabulated $\{2.7858\}$, that is, F-cal $>$ F-tab. Hence, we reject the null hypothesis $\{\mathrm{H} 0\}$ and accept Alternative hypothesis which means that the overall estimate has a good fit which also implies that our independent variables are simultaneously insignificant. We now concluded from the analysis that civil rights have positive significant effect on freedom of expression and associations in Nigeria.

\subsection{Discussion of Results}

In support with Minn, Srisontisuk and Laohasiriwong (2010) promoting has positive impact in the society and promotion also explores implementation strategies for fostering people's participation. Therefore, individual effort has positive significant effect to promote effective participation and rights to run for office in Nigeria $\mathrm{F}\{95, n=235\}=.60 .941, p<0.5$

From the findings of hypothesis two, civil rights have positive significant effect on freedom of expression and associations in Nigeria. Therefore, in support withAkeem (2010) repression of press freedom in Nigerian democratic dispensations. The study was to examine the expression of press freedom in Nigerian democratic dispensations $\mathrm{F}\{95, n=235\}=$ 175.861, $p<0.5$. Suntai and Targema (2017) submit that, democracy entails freedom of each individual to participate in the political community's self-government.

\subsection{Conclusion}

Nigeria's democracy is still a deficient, fragile, fledging and nascent democracy with enormous gaps and loopholes, little wonder it has ranked lowest in past good governance indicators ratings. Overcoming the multi-variegated malaises that is besieging Nigeria's democratic governance would involve ideological and philosophical restructuring of civil society. Nigeria, however, remains at a crisis, due to deep-seated ethnic animosity as well as the failure of contemporary activism and civil society to redeem the nation from schismatic ills rooted in its colonial foundations. Finally,individual effort has positive significant effect to promote effective participation and rights to run for office in Nigeria and civil rights have positive significant effect on freedom of expression and associations in Nigeria.

\subsection{Recommendation}

1.The study recommends that if the ongoing democratic process in Nigeria is to be reformed, and consolidated for overall national development. Thereshould be urgent need for the civil society to be repositionedand reinvigorated ideologically to become more active performing its multifaceted role in governance.

2. Government should collaborate and render free legal services to transparency, equity, accountability, freedom of speech, thought, association, advocacy, civic education, judicial freedom and accessibility, economic and social empowerment in the democratic process 


\section{References}

1. Abbott, L.F. (2019). Defending liberty: The case for a New Bill./ISR/Google Books

2. Abdullateef, U (2010). Dividend of democracy in Nigerian Issues and Challenges for National Growth and Development. Journal of Economic Perspectives, 16(4);185-205.

3. Adejumobi, S. (2004). Democracy, good governance and constitutionalism in Africa. In S. Odion-Akhaine (ed) Governance: Nigeria and the World. Lagos: Centre for constitutionalism and demilitarization (CENCOD).

4. Adejuwon, K.D. Okewale, R.A. (2018). The challemhes of democracy and development in Nigeria. International Journal of Social and Policy,7(1);1-12.

5. Aiyede, R.E., (2003). The dynamics of civil society and democratization process in Nigeria", Canadian Journal of African Studies,39(1).

6. Ake, C. (1996). Democracy and development in Africa. the Brookings institution, Washington, DC. USA.

7. Akeem, A.A. (2010). Repression of press freedom in Nigerian democratic dispensations. Africa Development Journal, 3:25-47.

8. Anyiwe, M.A. and Oziegbe, A. (2006). Democracy and economic growth: Statistical evidence from Nigeria 1960-2002. Journal of Applied Sciences, 6: 257-265.

9. Awojobi, O. N., Ayakpat, J. and Oladimeji, D.A. (2014).15 years of uninterrupted democracy in Nigeria what is the correlation between democracy and development? International Journal of Economics, Commerce and Management United Kingdom, 2(8).

10. Balot, R. K. (2009). A Companion to Greek and Roman Political Thought. John Wiley and Sons

11. Bernie, D. J. (2002). Critical race theory: New strategies for civil rights in the new millenium? Harvard Blackletter Law Journal, 18:1-90.

12. Business Dictionary, (2019). Civil right. Retrieved from http://www.businessdictionary.c om/definition/civil-rights.html

13. Business Dictionary, (2019). Freedom of expression. Retrieved from http://www.business dictionary.com/definition/freedom-of-expression.html.

14. Carpentier, N. 2012). Theconcept of participation. if they have access and interact, do they really participate? Retrieved from https://pdfs.semanticscholar.org/d03d/8837c6945c273 13c7149ba7f10331c922841.pdf

15. Chimaroke, M. (2015). Civil society and democratization in Nigeria: A Historical Perspective. American International Journal of Social Science, 4(5);1-12.

16. Chukwudi, J.O. (2017). Political culture, democracy and development in Nigeria. International Knowledge Sharing Platform, 1(2);1-5.

17. Diamond, L., (1999). Developing democracy: Towards consolidation, Baltimore: John Hopkins University Press.

18. Ibrahim, M.O. (2013). Development index: Nigeria among the Poorest, Failing States.

19. Idris, A.J. (2013).Democracy and development in Nigeria: Is there a link? Arabian Journal of Business and Management Review,,3(3);1-10.

20. Ikelegbe, ,A.O.,(2017). Civil society and democratic consolidation in Africa: Issue, problems and Prospects. Nigerian Journal of Policy and Development,6(2).

21. Kolawole,D. (2004). Nigeria: The struggle for democratic consolidation in a post colonial State. InAgaguA.A and Ola R.F (eds) Development Agenda of the Nigerian State, Ibadan: Fiag (Nigeria), Publishers.

22. Lysias, D. G. and Newman, E. U. (2015). Democracy and National Development in Nigeria: Challenges and Prospects. International Journal of African and Asian Studies, $13: 1-7$ 
23. Majekodunmi, A. (2012). Democratization and development in Nigeria: the fourth republic in perspective. International Journal of Academic Research in Economics and Management Sciences, 1(5);1-12.

24. Mamudu K.G \& Hassan, L.W. (2011). Legitimacy in Governance. Ibadan: Yolani Press.

25. Mary, C.Y. (2014). Activism success: A concept explication: A thesis submitted in partial fulfillment of the requirements of the degree of Master of Arts University of Washington, 1-107.

26. Michael, L. (2017). Democratic theory. Retrieved from https://www.oxfordbibliographies .com/view/document/obo-9780199756223/obo-9780199756223-0162.xml.

27. Minn, Z., Srisontisuk, S. and Laohasiriwong, W. (2010). Promoting people's participation in solid waste management in Myanmar. Research Journal of Environmental Sciences, 4(3);209-222.

28. Nwalonue, E.E and Ojukwu, N. (2012). legislative efficiency and democratic stability in the fourth republic governance and politics of Nigeria: A Re-appraisal of National Assembly. Kuwait Chapter of Arabian Journal of Business and Management Review, 1(9): Ma

29. Ofoegbu, J.U. (2013). The place of human rights in Nigeria's democracy. Ogirisi: A new Journal of African Studies, 10:1-19.

30. Ojekunle, A.A. (2017). Freedom of speech, tool for advancing liberty in Nigeria. Retrieve d from https://www.studentsforliberty.org/2017/07/09/freedom-speech-tool-advancingliberty-nigeria/.

31. Omede, A. J. and Bakare, A. R. (2014). The impact of civil society organizations on sustainable development in developing countries: The Nigerian experience. An InternationalMultidisciplinary Journal, Ethiopia, 8 (1);205-227.

32. Osondu, M.O. 2014). Democracy and political participation in Nigeria: The case of Imo State in the 2007 general elections. InternationalJournal of Development and Management Review, 9(1); 1-17

33. Owen, B. (2012). What is development? Retrieved from https://www.cgdev.org/blog/what-development.

34. Przeworski, A. (1991). Democracy and the Market. Cambridge University Press. pp. 1014.

35. Regilme, S.S. (2014). The social science of human rights: The need for a second image reversed: Third world quarterly, 35(8);1-10.

36. Social protection and Human Rights (2019). Ensure meaningful and effective participation.https://socialprotection-humanrights.org/framework/principles/ensuremeaningful-and-effective-participation/

37. Tolu, L. and Ogunro, V. O. (2012). Democracy and development in Nigeria. International Journal of Development and Sustainability,1(2);448-455. 